\title{
Political ecology of asymmetric ecological knowledges: diverging views on the eucalyptus-water nexus in the Taita Hills, Kenya
}

\author{
Johanna Hohenthal ${ }^{1}$ \\ Marinka Räsänen \\ Paola Minoia \\ University of Helsinki, Finland
}

\begin{abstract}
Environmental resource management policies worldwide have long insisted on the need to involve local communities and their diverse ecological knowledges in management planning and decision-making. In SubSaharan post-colonial countries, however, formal resource management is still largely dominated by bureaucratic governance regimes that date back to colonial power structures and that rely mainly on professional or formal knowledge. In this study, we use a political ecology approach to analyze disputes over eucalyptus plantations in the Taita Hills, Kenya. The approach recognizes the plurality of socially constructed and powerladen perceptions of environmental resources. We found that local people regard eucalyptus plantations not only as a threat to local water resources but they also highlight historical injustices and the loss of control over, and cultural relationships to their land. Bureaucratic resource management institutions, however, support the planting of eucalyptus to meet national demands for commercial forestry. Management officials also plead a lack of "valid" evidence for the negative impacts of eucalyptus on local water resources, diverting attention away from the formal environmental governance system which has unequal sharing of benefits, unclear policies, and internal incoherence. Recognition of historically rooted asymmetries of knowledge and power provides a step towards social transformation, ending a long-standing reproduction of subalternity, and promoting environmental justice and pluralism in decision-making.
\end{abstract}

Keywords: bureaucratic knowledge; environmental justice; eucalyptus; Kenya; knowledge asymmetries; local ecological knowledge; political ecology; resource management

\section{Résumé}

Les politiques de gestion des ressources environnementales dans le monde insistent depuis longtemps sur la nécessité d'impliquer les communautés locales et leurs diverses connaissances écologiques dans la planification, l'aménagement et la prise de décisions. Dans les pays post-coloniaux subsahariens, cependant, la gestion formelle des ressources est encore largement dominée par des régimes de gouvernance bureaucratique qui remontent aux structures de pouvoir coloniales et qui reposent principalement sur des connaissances professionnelles ou formelles. Dans cette étude, on propose une approche d'écologie politique pour l'analyse des disputes sur les plantations d'eucalyptus dans les collines de Taita au Kenya. L'approche reconnaît la pluralité des perceptions sur les ressources environnementales en tant que socialement construites et chargées des relations de pouvoir. On a constaté que pas seulement les populations locales considèrent les plantations

\footnotetext{
${ }^{1}$ Johanna Hohenthal, PhD student, Department of Geosciences and Geography, University of Helsinki, Finland. Email: johanna.hohenthal "at" helsinki.fi. Marinka Räsänen, MSc. Email: marinka.rasa "at" gmail.com. Dr. Paola Minoia, Adjunct Professor, Development Studies, Department of Political and Economic Studies, University of Helsinki, Finland. Email: paola.minoia "at" helsinki.fi. We are grateful to all those people in the Taita Hills who participated in the study and shared their valuable knowledge with us. We also thank Emmah Owidi, Belinda Andersson, Mwadime Mjomba, Dawson Mwanyumba, Darius Mwambala Kimuzi, and Granton Righa for their assistance in data collection and in organizing the workshops. Professor Petri Pellikka and his TAITAWATER project, funded by the Academy of Finland, are thanked for the financial support. Johanna Hohenthal also received partial funding from the VALUE Doctoral Program, funded by the Academy of Finland. The Taita Research Station of the University of Helsinki is thanked for logistical support. We would also like to express our sincere gratitude to Dr. Aili Pyhälä, Dr. Tiina Kontinen and Professor Anja Nygren for their valuable feedback on the earlier drafts of the article, as well as to Professor Simon Batterbury and two anonymous JPE reviewers for their useful comments that helped to improve the manuscript for publication.
} 
d'eucalyptus comme une menace pour les ressources en eau locales, mais aussi qu'elles mettent en évidence les injustices historiques et la perte de contrôle et de relations culturelles avec leurs terres. Cependant, les institutions de gestion des ressources bureaucratiques soutiennent les plantations d'eucalyptus pour répondre aux demandes nationales de foresterie commerciale. En outre, ils invoquent l'absence de preuves «valables» des impacts négatifs de l'eucalyptus sur les ressources en eau locales, détournant l'attention du système officiel de gouvernance environnementale qui partage inégalement les avantages et, au même temps, agit par des politiques peu claires et incohérentes. Par contre, la reconnaissance des asymétries historiquement enracinées du savoir et du pouvoir constituerait un pas en avant vers la transformation sociale, mettant fin à une reproduction de la subalternité de longue date et promouvant la justice environnementale et le pluralisme dans la prise de décisions.

Mots-clés: connaissances bureaucratiques; justice environnementale; eucalyptus; connaissances écologiques locales; écologie politique; Kenya

\section{Resumen}

Las políticas de gestión de recursos ambientales en todo el mundo han insistido durante mucho tiempo en la necesidad de involucrar a las comunidades locales y sus diversos conocimientos ecológicos en la planificación de la gestión y la toma de decisiones. Sin embargo, en países poscoloniales subsaharianos, la gestión formal de los recursos aún está dominada en gran medida por regímenes burocráticos de gobernanza que se remontan a las estructuras de poder coloniales y que se basan principalmente en el conocimiento profesional o formal. En este estudio, se propone un enfoque de ecología política para analizar disputas sobre plantaciones de eucalipto en las colinas de Taita en Kenia. El enfoque reconoce la pluralidad de las percepciones de los recursos ambientales como socialmente construidas y cargadas de relaciones de poder. Se ha observado que la gente local no solamente considera las plantaciones de eucalipto como una amenaza para los recursos hídricos locales, sino que también destacan las injusticias históricas y la pérdida de control y las relaciones culturales con sus tierras. Sin embargo, las instituciones burocráticas de gestión de recursos apoyan las plantaciones de eucaliptos para satisfacer las demandas nacionales de silvicultura comercial. Además, los funcionarios de gestión también aducen la falta de pruebas "válidas" de los impactos negativos de los eucaliptos en los recursos hídricos locales, desviando la atención del sistema formal de gobernanza ambiental que tiene una repartición desigual de beneficios y, al mismo tiempo, mantiene políticas poco claras e incoherencias internas. Por el contrario, el reconocimiento de las asimetrías de conocimiento y poder históricamente enraizadas proporciona un paso hacia la transformación social, poniendo fin a una prolongada reproducción de la subalternidad y promoviendo la justicia ambiental y el pluralismo en la toma de decisiones.

Palabras clave: conocimiento burocrático; justicia ambiental; eucalipto; conocimiento ecológico local; ecología política; Kenia

\section{Introduction}

We used to have a source of a nice spring [...], and our drinking water since I was young used to come from there. So, when this tree grew up, the water dried up. So, we went and cut it and the water started coming up again! So, I have proof! [...] I'm convinced. But they've written many papers, you may have read them, some supporting some against. So, it's not clear. [...] We are not sure. (Water project chairman, Wundanyi, interview, 2013)

This story, told by a chairman of a community-based water project, illustrates a common local observation of the declining water resources caused by the planting of exotic water-exigent eucalyptus trees in the Taita Hills, Kenya. It also reflects uncertainty about the formal knowledge provided by the forest management authorities regarding the negative impacts of these trees on water resources. Forest officers often placate peoples' concerns over eucalyptus with ambiguous 'scientific' explanations that contradict lay experiences, leaving the community with a sense of frustration and the problem unresolved. 
The dispute surrounding eucalyptus is part of a wider discourse around decreasing water resources in the Taita Hills, which is as a complex 'wicked problem' with multiple socio-ecological drivers (Hohenthal, Owidi, et al. 2015; Hohenthal, Minoia, and Pellikka 2017). This study focuses on the challenges in building dialogues between local people and forest management officials, viewed from the perspective of framing and structuring environmental policy problems. By doing this we aim to contribute to a transition movement towards politics based on diverse knowledges (Tengö et al. 2014). Reaching solutions would require rich participation and open dialogue between local people and decision-makers (Hurlbert and Gupta 2015).

Many international agreements and guidelines support the participation of local people and integration of their local ecological knowledge into modern natural resource management (Millennium Ecosystem Assessment Board 2005; United Nations 2008, 2015). The practical application of this principle, however, involves many obstacles, starting with the need to recognize and connect different knowledge systems (Goldman 2007; Raymond et al. 2010; Sillitoe 2007; Tengö et al. 2014; Turnbull 2000). Problems typically arise when local ecological knowledge is evaluated based on the validation criteria and conceptualizations of western ecological science that hold a hegemonic position in informing environmental management (Nadasdy 1999; Nygren 1999; Watson 2013). Moreover, the official management systems run by state agencies are often slanted by political and economic interests and are based on coded, often outdated, ecological principles of reductionist and selective professional and bureaucratic knowledge (Fleischman and Briske 2016; Hunt and Shackley 1999), which poses further challenges to building dialogues with knowledges produced in complex local settings. On the other hand, many local communities in the developing world have undergone cultural oppression and subalternization under colonial and post-colonial regimes, causing negation and distancing from their traditional knowledge and producing hybridization and assimilation with dominating cultural practices and western knowledge systems (Bhabha 1995; Gramsci 1971; Spivak 1988). This weakens their selfconfidence and capacity to defend local perceptions during environmental negotiations, for example, in confrontation to the interests of commercial plantation forestry.

The environmental policy problem we focus on concerns the role of eucalyptus plantations in changing water resources and land use, an issue that is debated worldwide in scholarship and political arenas. Large-scale industrial plantations administered by national or international companies have caused social conflicts due to associated environmental impacts (Gerber 2011; Gerber and Veuthey 2010; Gerber, Veuthey, and MartínezAlier 2009). In Kenya, the eucalyptus problem has been highlighted, for example, by the Green Belt Movement and its founder, the Nobel Prize laureate Wangari Maathai, who warned about the negative effects of eucalyptus plantations and defended the role of indigenous forests for water conservation (Maathai 2004). By using a political ecology approach and focusing our analytic gaze on the point where perceptions of the impacts of eucalyptus trees on water resources diverge, we aim to increase understanding about the asymmetric dialogue between the local people and environmental management authorities in the Taita Hills. We are interested in how the 'eucalyptus problem' is framed by the different government bureaucrats and local actors involved in resource management. What kind of power dynamics do the framings mask? How are different framings produced historically, and how do they impact the ways the 'eucalyptus problem' is structured, including the search for solutions? By posing these questions we aim to highlight the weaker local perceptions and promote transition towards increased democracy in policy making.

We argue that the current professional discourse surrounding eucalyptus in the Taita Hills reproduces the subaltern position of the local people in environmental management, since it does not recognize their arguments about the negative impacts of eucalyptus as a legitimate knowledge basis for decision-making. Moreover, the formal management system serves capitalist interests, discouraging a plurality of values (cultural, religious, intrinsically ecological etc.) that people traditionally attribute to the forests. These conditions are at the basis of environmental injustice and degradation of resources. Altering the way forests are governed requires building an open dialogue between the different actors and mutual recognition and legitimization of each other's perceptions and knowledges, political agency and rights. 


\section{Political ecology of knowledges and perceptions}

Political ecology provides a useful framework for studying the power dynamics producing environmental changes and the differences in resource access across groups and individuals (Robbins 2012; Turner 2014). It exposes how knowledge systems play a fundamental political role (Paulson, Gezon, and Watts 2003). Political ecologists also recognize that the knowledge and perceptions of environmental changes are embedded and shaped by social context, including the political economic and historical trajectories of power (Bixler 2013). Ecological knowledge and perceptions also have capacity to affect decision- and policy-making as they provide "a 'meta-condition' for the exercise of power" (Avelino and Rotmans 2009: 558).

Ecological knowledge and perceptions are produced within social systems, which have specific values and priorities, producing knowledge asymmetries with respect to other systems, which makes communication across them challenging (Noe et al. 2015). As we will discuss later, relations of dominance and asymmetric power relations between different groups cause assimilation of, rather than egalitarian recognition of, different knowledges. Moreover, knowledge systems guiding environmental actions are not entirely uniform, in a locality or intergenerationally, as they are also constituted by individual perceptions that draw from personal tacit and embodied knowledge produced in repeated interaction with local environments (Fernández-Llamazares et al. 2016; Pyhälä et al. 2016). The conceptual distinction between knowledge systems and individual perceptions, however, is mainly an analytical but not an evaluative one (i.e., where perceptions are considered less valuable than knowledge). In fact, perceptions can be more important than established knowledge in influencing environmental dialogues as they are what people bring into them in the first place. Distinctions drawn between knowledge systems and perceptions is also separate from a philosophical debate about the nature of truth, and whether it is reflected adequately in non-western perceptions and knowledge (Yeh 2016). Here we assume that various knowledges and perceptions can be viewed as legitimate within their own context (Berkes 2012; Bixler 2013; Sillitoe 2007), and interrogate them "primarily within rather than across knowledge systems" (Tengö et al. 2014: 579).

Local ecological knowledge systems and perceptions are socially constructed, dynamic and continuously emerging, reshaped in complex negotiations and hybridizations between endogenous and exogenous elements (Berkes 2012; Gómez-Baggethun et al. 2013; Pottier 2003). 'Local' refers to the spatial level at which the knowledge holders operationalize their knowledge. It does not refer to the spatial coverage of the knowledge content itself that can be, for example, about national or international politics or about 'global' scientific understanding of ecosystem dynamics (Nightingale 2015). Shared experience of place and social norms inform local ecological knowledge, while embodied experience in a cultural and political-economic context, and a person's individual social and political position, lead to variations in perceptions across a community.

The survival and resilience of local ecological knowledge systems require that their regeneration capacity and applicability are preserved and transmitted across generations (Gómez-Baggethun and ReyesGarcía 2013; Jandreau and Berkes 2016; Pearce et al. 2015). Local knowledge systems continuously adapt to new conditions and become hybridized by contact with external cultures (cf. Dear and Burridge 2005; GómezBaggethun et al. 2013). Hybridization is also influenced by power relations in intercultural encounters (Bentley 1993; Jandreau and Berkes 2016). Nygren (1999: 271) describes this as knowledge reconfiguration "within the ongoing struggles over resources and representations" that are also inevitably affected by peoples' competitive roles, and their gender, class, age, religion and political standing. Colonial oppression has eroded many significant elements and transfer mechanisms of local ecological knowledge systems, and thus contributed to the assimilation of external knowledge, where significant parts of traditional culture and knowledge are abandoned (Turner et al. 2000). In East Africa, weakened knowledge systems have also been subject to further structural and epistemological oppression in the post-colonial period, as we will demonstrate in this article.

In the post-colonial countries of the global South, local management procedures are influenced by state policies and its political and economic interests, and by western rather than local knowledge and values (Cáceres, Silvetti, and Díaz 2016; Keeley and Scoones 2003; Seghezzo et al. 2011). Formal knowledge of environmental management can be called professional ecological knowledge that Fleischman and Briske (2016: 2) consider to be "founded upon codification of broad ecological principles", for example through scientifically outdated best management practices and technical guidelines, used "to inform and legitimize standard agency 
programs and protocols, to support uniform implementation, and to encourage user compliance." It guides the everyday operation of environmental management together with bureaucratic/administrative knowledge that involves specialized administrative procedures (Edelenbos et al. 2011). In addition, the perceptions of local management officers are also influenced by their own experiences and tacit knowledge gained during their careers (Boiral 2002).

The success or failure of an environmental dialogue is affected by power relations and trust, as well as consensus on problem definitions, whether relevant knowledge exists, and goals. This is suggested by the "split ladder of participation" diagnostic framework, by Hurlbert and Gupta (2015). According to this framework, unstructured wicked problems emerge in situations where high uncertainty and disagreement about knowledge and values are combined with asymmetric power relations and lack of trust between actors. These problems can only be solved through a challenging and highly participatory process of "triple loop learning" of power dynamics and values in a socio-ecological context, which leads to changes in underlying worldviews accompanied by the transformation of the whole governance structure (Pahl-Wostl 2009). Building trust is a key aspect of learning, expanding public participation and addressing wicked problems with a moderately structured approach (with agreement either on values, or on the basis of knowledge claims).

In this study, we interrogate the dynamic and unequal relationships between local and bureaucratic actors and the specific policy problem of eucalyptus plantations using this framework. By so doing, we aim to increase understanding of the social construction of local peoples' and bureaucrats' ecological perceptions and knowledge as well as their positionalities. We argue that our approach could help to build trust, avoiding bureaucratic hegemony by supporting local communities, and thus enabling reciprocal learning.

\section{Transformation of forests, knowledge and management in the Taita Hills}

The greatest historical extent of the indigenous forest cover in the Taita Hills is unknown. It has been estimated, however, that over 90 percent of the original forests have been lost during the past 200 years (Newmark 1998). Before the colonial era, some forests were already cleared for agriculture (Hobley 1895), but ecosystem change became more extensive during the colonial and post-colonial periods. In the beginning of the twentieth century, British settlers introduced exotic fast-growing tree species, including eucalyptus (Eucalyptus spp.), cypress (Cupressus lusitanica) and pine (Pinus patula) in the area, but planting spread more quickly after the end of the colonial period in 1963 when the independent Kenyan government realized the commercial value of those trees, especially eucalyptus, and the local people adopted the idea (Himberg 2011). The expansion of eucalyptus plantations was linked to a worldwide promotion of eucalyptus by international organizations, such as the United Nations Food and Agriculture Organization (FAO), to enhance the renewable resource base in developing countries (Doughty 2000). Between the 1950s and 2000s, together with agricultural expansion, the planting of exotic trees contributed to a 50 percent decrease in the remaining indigenous forest patches while the total forested area remained unchanged (Pellikka et al. 2009). Currently, plantations vary from groups of individual trees to larger plantations and are both state-owned and private. The transformation of the indigenous forests into timber plantations linked Taita's forests to the global market value chains and introduced a capitalist discourse into local environmental management. At the time of their introduction, the eucalyptus seedlings were given to people for free by the forest office and without proper guidelines on where and how to plant them (Himberg 2011). Thus, even today eucalyptus is found growing along streams and near springs, and due to strictly controlled timber logging regulations, the trees are not removed despite local requests.

The Taita people, whose Bantu-speaking ancestors already inhabited the hills in the mid-sixteenth century (Bravman 1998; Merritt 1975), have a deep understanding of the dynamics between indigenous forests and water resources. This is embedded in their traditional ecological knowledge and rituals (Himberg 2011). Traditionally, Taitas have considered certain indigenous tree species capable of attracting rain or of forecasting it, retaining water and controlling soil erosion and water quality. In the past, many indigenous forests were also regarded as sacred groves or fighis, only accessed by powerful elderly men capable of communicating with the ancestors. Some fighis were also important places for rainmaking rituals, enhancing the cultural link between indigenous forests and water at a landscape level. Despite a general loss of cultural respect for the indigenous forests and their ritual uses, especially among the younger generations, some larger patches and individual trees 
associated with magical powers still remain. The eucalyptus forests, however, have become a significant part of the local ecosystem and peoples' observations of their negative impacts have also been adopted as part of the local ecological knowledge system, as we will show later.

During the colonial period (1895-1963) and the first post-independence decades, formal environmental management in the Taita Hills moved away from traditional communal management towards increasing state control (Bravman 1998; Fleuret 1985; Harris 1986). First kin groups (kichugu) still owned some land and resources communally in different agroecological zones, while other areas were taken and controlled by the British, and some large estates with an agrarian workforce were established, for example for the production of sisal in Mwatate. Following the Land Adjudication Act of 1967, the scattered communal land holdings were consolidated, and they became the private property of individual households (Waaijenberg 2000). But watercourses and certain forested areas remained as state property. Since the 1980s, Kenya has followed the tendency to 'neoliberalize' natural resource governance, as suggested by global financial institutions, combining privatization with decentralization of public institutions in order to decrease public spending (Heynen et al. 2007; Minoia 2012). This is visible in the organization of forest and water governance in Kenya. In the forest sector, Community Forest Associations (CFAs) have recently been established as decentralized units for forest management, and are supposed to negotiate the use and benefit sharing of the local forest resources with the Kenya Forest Service (KFS) (Republic of Kenya 2005: 275, sec. 46(2)). Local communities are also involved in local Water Resources Users Associations (WRUAs) (Government of Kenya 2002: 953, sec. 15(5)), mandated to develop and implement Sub-Catchment Management Plans compliant with the needs of catchment conservation (Water Resource Management Authority 2012). In both sectors, however, the communities lack real capacities to participate in management and allegedly, the ultimate decision-making has remained centralized in government ministry offices (Chomba et al. 2015; Mumma 2007; Ogendi and Ong'oa 2009; Thygesen et al. 2016).

The 2014 Kenyan forest policy acknowledges the role of local communities and their traditional ecological knowledge for forest protection (Republic of Kenya 2014), consistent with the 2010 Kenyan constitution which promoted decentralization and citizens' participation in environmental management, protection and conservation (Republic of Kenya 2010: 49, article 69 (d)). The Constitution dictates that the state "shall protect and enhance intellectual property in, and indigenous knowledge of, biodiversity and the genetic resources of the communities" (Republic of Kenya 2010: 49, article 69 (c)). However, this limited interpretation of resource control sees the value of local ecological knowledge mainly in capitalist terms as the property of communities, stressing its commercial application rather than its value for cultural survival and resource management.

\section{Methods}

This study draws on fieldwork carried out in the Taita Hills from 2013 to 2014 to study various aspects of water and related land and forest resources use and management (Figure 1). In that project, we employed multiple qualitative methods: semi-structured interviews, focus group discussions, participatory mapping, timelines, transect walks, participant observation and informal conversations (Hohenthal, Räsänen, et al. 2015; Hohenthal et al. 2017). In addition, we collected secondary information from previous studies and governmental and NGO sources that helped us to triangulate information. This extensive data collection gave us a wide picture of the different understandings of the forest-water dynamics in the area.

The first dataset for the current study consisted of 44 interviews with local and regional institutional and organizational actors in the water and forest sectors and related fields: members of local water related community groups, local district officers of government ministries and representatives of local government, the administration, private companies and locally based non-governmental and community-based organizations (NGOs and CBOs) (Table 1). The sampling of these interviews was done in a non-random and purposive way by using the 'snowball' method. All these informants hold a mandate regarding resource management and thus their perceptions stem from the bureaucratic/professional ecological knowledge system, at least in part. It must be noted, however, that some informants, especially chiefs and village elders, had a dual role as representatives 
of state institutions on the one hand, and as members of the local community on the other. Some of them had adopted bureaucratic perceptions of eucalyptus, while the others better reflected community concerns.

The second dataset was formed by the information collected in four workshops that we organized to create conversation among local people and bureaucrats about water and related ecosystem management. The workshops in Wundanyi and Mwatate villages in 2013 were with representatives of organized community groups, and included various participatory activities such as sketch mapping, timelines and focus group discussions. The workshop participants in 2014 included representatives from community groups, state institutions and non-governmental organizations and the program consisted of discussions about the various water-related problems identified in the previous workshops.

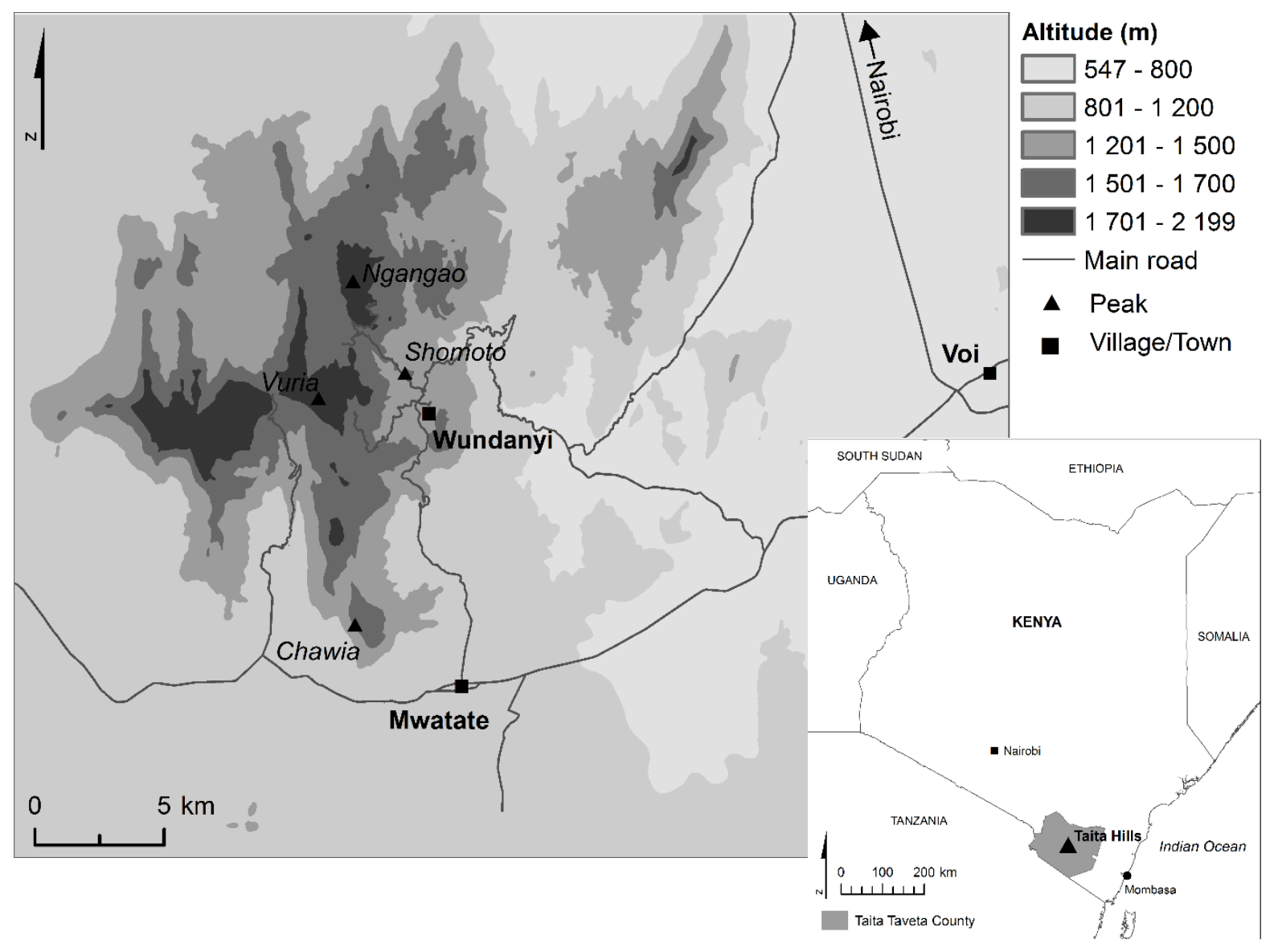

Figure 1: Taita Hills in South-East Kenya. Source: authors.

\section{Data analysis}

The data analysis and positioning of the eucalyptus problem in the 'split ladder of participation' framework was based on a heuristic understanding of all the data we gathered during our research project. A content analysis was first carried out, in which the transcribed interviews and workshop discussions were coded according to the different perceptions of the forest-water dynamics that emerged from the data. After that, discourse analysis was used to focus our attention to the specific legitimizations the informants employed in the context of framing the eucalyptus problem or in talking about the water-forest nexus. By so doing, we were able to analyze the social embeddedness of the problem framing and structuring, and the power relations that 
the positionalities and subjectivities in the perceptions and discourses revealed (Bixler 2013). Thus, the results presented and discussed in the following sections do not aim to deconstruct the science of eucalyptus-water nexus but to reveal the challenges in building a dialogue by analyzing the different framings and structuring of the problem in its historical and socio-political context.

\begin{tabular}{|c|c|c|}
\hline Organization /Institution & Spatial scale of jurisdiction ${ }^{2}$ & Category \\
\hline $\begin{array}{l}\text { Water Resource Management } \\
\text { Authority sub-regional office } \\
\text { (5 officers, Mombasa) }\end{array}$ & Regional (Coast) & $\begin{array}{l}\text { State bureaucrats } \\
\text { (Total: } 10 \text { institutions; } \\
31 \text { officers) }\end{array}$ \\
\hline $\begin{array}{l}\text { Coast Water Service Board Area } \\
\text { coordinators ( } 2 \text { officers, } \\
\text { Wundanyi and Mwatate) }\end{array}$ & District & \\
\hline $\begin{array}{l}\text { National Drought Management } \\
\text { Authority, Early Warning } \\
\text { coordinator }\end{array}$ & County & \\
\hline $\begin{array}{l}\text { Agricultural officer (2 officers, } \\
\text { Wundanyi and Mwatate) }\end{array}$ & District & \\
\hline Kenya Forest service (3 officers) & County & \\
\hline District Commissioner, Mwatate & District & \\
\hline District Officer, Wundanyi & District & \\
\hline County Council Clerk, Wundanyi & District & \\
\hline Area chiefs/sub-chiefs (8 chiefs) & Location /Sub-location & \\
\hline $\begin{array}{l}\text { Village Elders (from } \\
7 \text { locations/sub-locations) }\end{array}$ & Village & \\
\hline $\begin{array}{l}\text { Water Resource Users Association } \\
\text { committees (4 groups) }\end{array}$ & $\begin{array}{l}\text { Sub-catchment (Mwatate and Voi } \\
\text { rivers) }\end{array}$ & $\begin{array}{l}\text { Community groups } \\
\text { (Total: } 12 \text { groups) }\end{array}$ \\
\hline $\begin{array}{l}\text { Community water project } \\
\text { committees (8 groups) }\end{array}$ & & \\
\hline Taita Taveta Wildlife Forum & County & $\begin{array}{l}\text { Non-state (NGO) } \\
\text { (Total: } 1 \text { organization) }\end{array}$ \\
\hline
\end{tabular}

Table 1: Institutional and organizational actors interviewed.

\section{Results}

The results are structured based on the local and bureaucratic framings of the eucalyptus problem, respectively. The challenges in dialogue building between the actors are discussed thereafter. To illustrate the major findings, we present key quotations from the research data.

\section{Community actors' framing of the eucalyptus problem}

In the workshops, the local community groups strongly voiced their concern over the negative impact of the eucalyptus trees on water resources and their contribution to the loss of indigenous forests and associated cultural values, which raised lively discussions. Analysis of the contextual data showed that there are also people in the Taita Hills who do not share this perception, and some think that the income from timber production outweigh the potential negative impacts on water resources. Yet, negative attitudes towards exotic

\footnotetext{
${ }^{2}$ Marked according to the administrative structure prior to County Government inauguration in May 2013.
} 
forests in general, and particularly eucalyptus plantations were widespread among Taitas, especially in the hills area where the eucalyptus plantations are more prominent and have replaced the indigenous forests. The negative attitude stemmed also from the historical marginalization of the Taitas' role in resource management, their loss of ownership of forests and unequal sharing of benefits from the species that invaded their ancestral lands. Local peoples' historical accounts shared in the workshops showed that the roots of the Taitas' oppressed position in forest resource management and ownership date back to the beginning of colonization and the arrival of Christian missionaries at the end of the $19^{\text {th }}$ century. Taitas' conversion to Christianity produced changes to their cosmological understanding and contributed in particular to the abandonment of beliefs and traditions related to sacred indigenous forests and the assimilation of western utilitarian values and knowledge accompanying the arrival of commercial forestry. This enabled the destruction of many sacred indigenous forests, fighis, and erosion of related protective practices during the $20^{\text {th }}$ century:

When the white men came to Africa, they told that these fighis are black magic, they don't have anything, you can cut them and they (Taitas) agreed. Initially, all the water towers were fighis, shrines. Nobody would go near there. (A middle-aged man, Mwatate workshop 2013)

Since colonial times, Taitas have also integrated experiential knowledge of the negative impacts of eucalyptus on water resources into their local ecological knowledge. For example, in Wundanyi, eucalyptus has become over time a symbol for the desiccation of landscapes as the community has realized that the trees were first introduced by the British settlers with a purpose to drain wetlands (Figure 2). When the conversion of the indigenous forests to exotic and mixed forests became more common after independence in the 1960s, people started to observe the ecological impacts of eucalyptus more widely. Stories of these observations have been transferred between generations and thus the historical perspective also shapes Taitas' current opinions of forest management:

When civilization was coming in, we had all trees indigenous but now we got [...] eucalyptus. [...] we started receiving trees from other countries, these exotic trees. So, the water level started going down instead of going up. So, this is a problem we are facing. We need to maintain the forest and plant indigenous trees, so we can have more water. (A middle-aged man, Wundanyi workshop, 2013)

The period of colonization also included several land grabs where the indigenous forest areas were 'taken' from the community, becoming a government resource and turned into exotic tree plantations. A history of restrictive forest use policies has allowed the benefits of eucalyptus to flow mainly to the government, leaving the community without firewood and with water problems. This has caused frustration among Taitas and thus their resistance to eucalyptus symbolizes not only an honest fear of the looming water crisis, but also the unequal sharing of benefits. This is also a major historical source of mistrust between government and local people. Along with mistrust, the frustration manifests itself in a kind of ambivalence towards, and disowning of, the seized community lands:

And for that reason, now I can assure you, because it's in my village, that even now if it (Shomoto forest) catches fire during the day, nobody goes (to put it out). The whistle is blown Fire! Fire! Fire! But people are saying: YES! Because we don't benefit anything! They could at least have told people that people are free to pick the firewood that falls down from the blue gum (eucalyptus). They say: don't pick, you want to cut others which are growing. And that's not true anyway. (Village elder, Sungululu, interview 2013) 


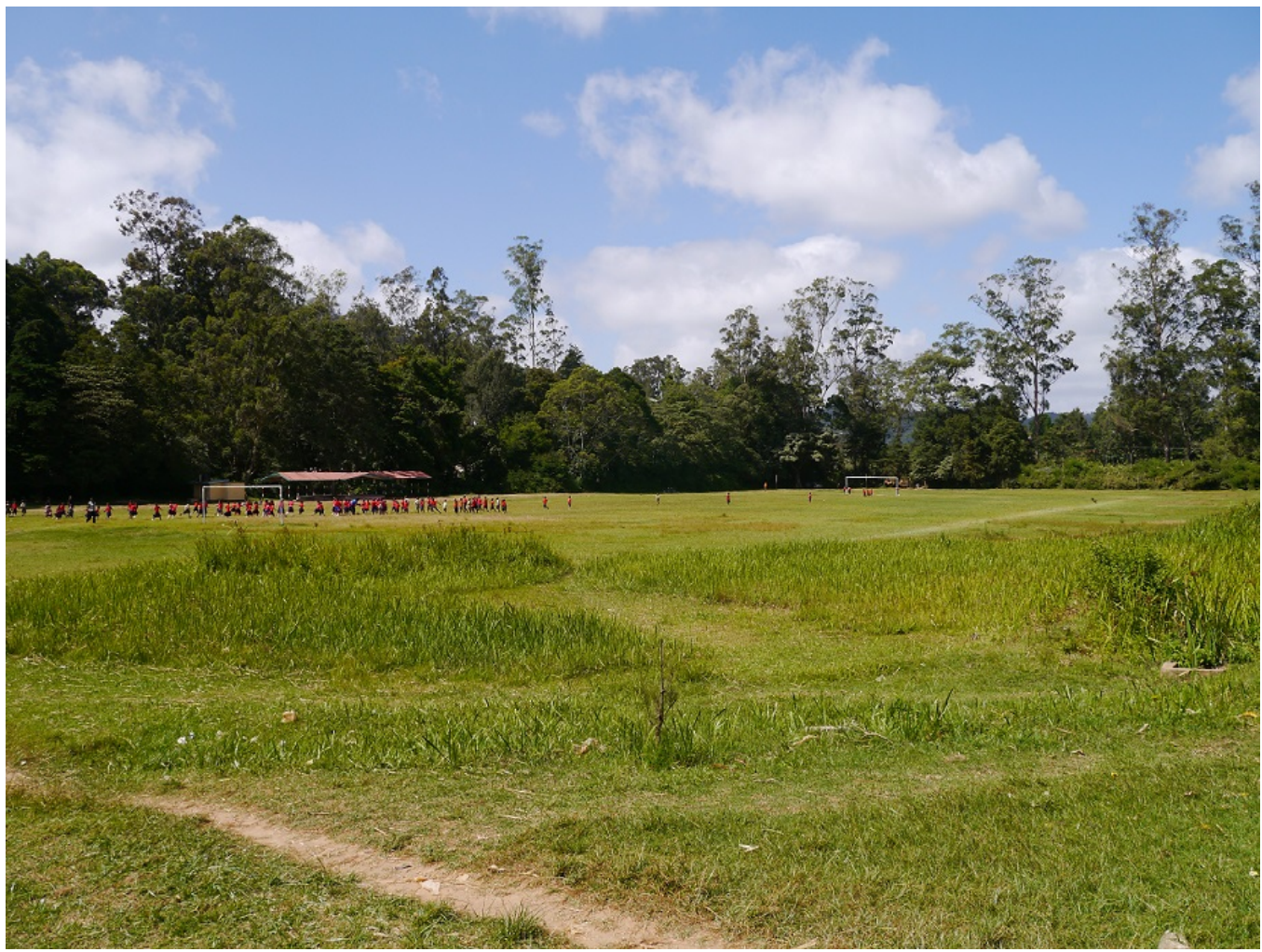

Figure 2: Dawson Mwanyumba Stadium in Wundanyi village is a former wetland that was desiccated by planting of eucalyptus trees to its margins. Source: authors.

To summarize, the general local people's framing of the eucalyptus problem focuses, on the one hand, on the negative impacts of the eucalyptus on local water resources and thus people's livelihoods and, on the other hand, on the loss of indigenous forests and associated cultural values due to exotic tree planting. Local people also recognize the economic benefits of eucalyptus, but claim that the plantations should not harm water resources and that the sharing of benefits should be equal.

\section{Bureaucratic perspectives on eucalyptus}

In the interviews with the state bureaucrats involved in forest management, it became clear that many of them had distanced themselves from the local question of the relationship between eucalyptus and lowering water tables and addressed the matter at a more distant policy level, not responding to the concerns of the community members directly. Instead, they framed the problem in a different way by highlighting economic benefits. For example, the officer of the Kenya Forest Service (KFS) defined the role of his institution as being a technical advisor on practical issues. He considered the economic value of the species, but did not express any direct opinion on the problems eucalyptus may cause. In the workshop, another officer responded to local claims about the negative impacts of eucalyptus on water resources and 'clarified' the matter from an 'objective' perspective:

I am not here to protect the eucalyptus trees. I want to give a scientific view on this issue. Eucalyptus does use a lot of water, that's the reality [...]. But one eucalyptus grows very fast, so if it grows so fast, it has to get enough water proportional to its growth rate, so the more water it takes, the faster it grows. [...] Therefore, I dismiss the myth that it uses more water, it only uses 
enough water to sustain its growth rate, but it does not use excess water. [laughter in the audience] It also transpires more water into the environment. So, it enhances the rainfall pattern. So, removal of eucalyptus should be gradual, the moment we clear all the eucalyptus, we shall have tampered with stemflow. Once we tamper with stemflow, then we have tampered with ground water storage, because all the water will go to seas and ocean. So, we need to remove the trees gradually, so that we shall have our recharging power. [...] We plant them for reason to get maximum returns. Eucalyptus were brought so as the Kenyan government could get timber at the shortest time possible, it was not our wish, the indigenous trees can't cover for the rate we're using timber. (District forest officer, Wundanyi workshop 2014)

In the context of the discussions in the workshop, this statement created laughter as the forest officer evaded earlier statements and observations of the community members on the impact of eucalyptus on the drying of the springs in their home areas. However, while he acknowledged the need to gradually remove the eucalyptus from some areas in order to control its invasion, he did not take a stand on the immediate removal of the trees next to certain water sources - a response many local people are still waiting for.

The KFS officers' perceptions of eucalyptus reflect the official guidelines produced by KFS and Kenya Forestry Research Institute (KEFRI) for planting the species (Kenya Forest Service 2009; Oballa et al. 2010). The guidelines rely on the results of the scientific studies that justify the planting of eucalyptus for commercial purposes on the grounds of its water use efficiency, and yet, on the other hand, caution against its planting in certain areas due to the potential - but not universally proven - risk that it may be harmful to local water resources. The guidelines numerically demonstrate that eucalyptus uses less water than, for example, Acacia

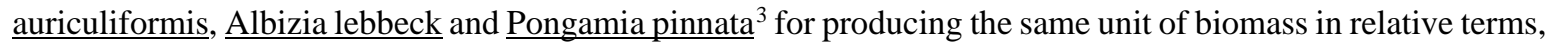
thus making it a 'water efficient species.' What is not highlighted here is that the total consumption of water per year by eucalyptus is greater in absolute terms than that of the other tree species that grow slower, although this can be interpreted from the guidelines. The KEFRI guidelines also state that the impacts depend on the species in question and local climatic and soil conditions. Thus, while the guidelines give a clear indication of the risks of eucalyptus to water resources, the ambiguous explanation diverts the focus back to water efficiency in biomass production, linked to the tree's economic value. This ambiguity of professional knowledge allows the bureaucrats to meander around the question of the impact of eucalyptus in local context, and to refrain from taking any concrete actions to remove eucalyptus trees close to water sources.

The national level forest policies are also unclear about eucalyptus. For example, the KFS representatives also said that they do have plans to start replacing the eucalyptus with indigenous species but there is no policy directive yet from the head of KFS in Nairobi to start the process. In addition, a major policy goal of the forest sector in Kenya, the achievement of 10 percent tree cover, has so far not specified any tree species for achieving the target outside agricultural land areas ${ }^{4}$, which has enabled massive commercial plantations of eucalyptus and other exotic tree species all over the country. This policy has likely contributed to the slow actions of KFS, as was shared by a representative of a local NGO:

The Forest Department doesn't want the eucalyptus trees removed, because they are thinking about reducing the tree cover. But Environment Department also was saying that [...] "remove all the eucalyptus, because they are exotic and they are a danger to our water sources". But there was that conflict of interest between the two governments. (Taita Taveta Wildlife Forum representative, Wundanyi workshop 2013)

\footnotetext{
${ }^{3}$ The compared species do not include many of those indigenous species that local people have traditionally considered beneficial for water resources in Taita (e.g., Mkongo - Ocotea usambarensis, Mkuy - Ficus sycomorus (L.), Mombo - Myrica salicifolia) (Himberg 2011).

${ }^{4}$ Regarding agricultural lands, the Agriculture Act on Farm Forestry Rules 2009 clearly dictates that "the species or varieties of trees planted should not have adverse effects on water sources, crops, livestock, soil fertility and the neighbourhood and should not be of invasive nature" and that the land owners are not allowed to grow or maintain any Eucalyptus species on wetlands and riparian areas (Government of Kenya 2009: 3).
} 
The conflict of interest and lack of coherence at higher levels of administration was also visible in the answers given by other government departments concerning the trees. While in principle, the different officers agree on the need to deal with the eucalyptus problem, the question of who takes responsibility for guarding the water catchment areas is still hanging in the air. Testimonies from different actors indicated that in the local as well as in the national context, the heart of the debate seemed to be the question of benefit-sharing of resources and responsibilities. Who will take responsibility, who will benefit, and who will lose if the eucalyptus trees are cut? This kind of problem-framing clearly differs from the local one, but at the same time it also takes a position by giving priority to the economic benefits and undervaluing local concerns over water resources.

\section{Challenges in collaboration between the community and bureaucratic actors}

Eucalyptus trees have become a policy problem, when framed from the local perspective, but the issue is clearly unstructured as the state bureaucrats and local inhabitants disagree on the basis of knowledge on their negative impacts on water resources and on the values that should guide replacing plantations with indigenous species. According to 'the split ladder of participation' framework, reaching a solution would require local participation and equal dialogue between different actors. So far, however, the attempts of the community members to approach the decision-makers with their concerns have been disappointing. People feel that professional explanations by the officers are distant from local realities, illustrated by the following discussion between two water project members:

Secretary: From my own research, about this blue gum (eucalyptus), I was asking one of the forest officers about it, then the explanation was: blue gum roots normally penetrate deeply, so it lowers the water table. And maybe from the water cycle there is that evapotranspiration, water going up, down, up again. So, if the blue gum is sucking a lot of water, it will not take it anywhere, it will just again go up and then recycle. So, with blue gum, it affects the rain. But the only problem, it will lower the water table.

Chairman: And that is my problem. Why should it lower that water table, because I'm unable now to use that water?! It is like the Chinese saying, they can make rain. So, they had this airplane, and they fly very high, drop this chemical and it takes about a half an hour for the rain to start, but the wind comes and blows that cloud, and it rains somewhere else. (laughs) So, this is like what you're saying, if it goes up, you're not guaranteed that that rain will come back here. It will rain somewhere else! (Water project members, interview 2013)

The lack of committed visible action from the forest officers makes the community members feel that they are victims of policies decided elsewhere, and by bureaucrats who are not responsible for the ecological consequences of their actions. Therefore, from the community perspective, the difficulties of collaboration with management officials stem from their lack of real power to influence decision-making, along with an unwillingness of the officials to address the problem. This feeling is reinforced by the responses of the forest officers highlighting the lack of evidence on the water question:

We have been trying to ask our leaders to allow us to uproot those (eucalyptus) trees and plant indigenous trees... Perhaps our water will be retained in those springs. We think those blue gums are the cause... but the government doesn't want to hear that, they say who has done research and known that these trees are drying up the rivers?! (Village elder, interview 2013)

The community members have been made aware that (scientific) "research" is the only valid and legitimate basis for decision-making and to some extent they have had no other choice but to adopt this attitude, which is reflected in their own expression of uncertainty. The officials do not trust local perceptions, and indeed the observations and assumed causalities between eucalyptus and decline in water resources are easy to criticize, because there are other factors simultaneously affecting water resources and consumption (e.g., population 
increase, changing agricultural practices). However, regarding scientific knowledge, there is also a knowledge gap created by a lack of information sharing. For example, according to a Wundanyi chief, the KFS had promised to do research on eucalyptus trees and their water consumption but they had not yet reported any findings to the community.

This inadequate flow of information has made the community fear that the government's plans to start phasing out the eucalyptus will remain as empty promises. The communities are told that the issue is being researched, but people are left without updated information. The suggestion by KFS to replace eucalyptus with indigenous species progressively is indeed justified near water courses, but what the communities find difficult to understand is the slow progress and why they cannot participate in removing individual trees that are clearly causing harm.

Despite changes in national policy towards more participatory forest management, the process of establishing the formal mechanisms of participation and benefit sharing, for example, through the Community Forest Associations (CFAs), has stagnated in the Taita Hills. At the time of fieldwork there were no groups that had signed an agreement with the KFS to share monetary benefits from the felling of eucalyptus trees. The Wundanyi Water Resource Users Association representative suspected that this was due to the reluctance of KFS to recompense the community. The representative of KFS, on the other hand, saw the lack of formal agreement as resulting from the CFAs not being fully functional. According to the standards of KFS, the groups cannot be counted as equal members in the negotiation table if they have not established economically viable income-generating activities and do not have a sound management plan:

You see now, when you negotiate, you negotiate with people who know exactly what they are defending, because it now becomes like a market situation. [...] But you see, now we cannot move to that extent, because 1) the CFAs don't have user groups which are actively involved in the relevant, the nature based industries which will give them upper hand to negotiate with us over the incomes, 2) the membership is amorphous [...] (Forest station manager, interview 2013)

While the officer also recognizes the need of KFS to use resources to 'mobilize' the community and perhaps to compensate their participation, the overarching logic of the governance framework still entails control and approval from higher levels in determining the terms of negotiation. This continues to reproduce the marginalization of local people in resource management as it does not give the community an opportunity to set or even influence the terms of negotiation that would eventually bring about community empowerment and self-governance.

\section{Discussion}

Our study has shown that local people frame the eucalyptus problem in the Taita Hills in terms of reviving local water resources, restoring Taitas' cultural relationship to the land and fixing the historical injustices of benefit-sharing. This finding is in line with, and elaborates on Smith's observation that the Taitas' concerns over eucalyptus reflect the protection of autochthonous values and resources from external forces (2008). In contrast, the bureaucratic framing primarily highlights responding to the national demands of commercial forestry. The bureaucrats do not recognize the historical injustices in resource ownership and benefit sharing, and address water problems only cursorily by referring to the lack of valid knowledge on the negative impacts of eucalyptus on water resources in individual cases. This reflects the particular "politics of truth" assigned to the hydrosocial territory of the Taita Hills, which through the logic of 'neoliberal multiculturalism' sidelines the local understanding of eucalyptus-water nexus as a problematic feature of water culture that does not align to economic goals of the government (Boelens et al. 2015: 2016).

Obviously, our study has not investigated the full range of eucalyptus issues, since it has focused only on the point of friction where perceptions diverge between two groups. This has, however, brought up a wider range of cultural and economic meanings attached to eucalyptus plantations. From the local perspective, it is also clear that even those farmers who make a profit from growing eucalyptus and have perhaps become estranged from the traditional values of indigenous forests, must live with the risk of local water resource 
depletion. They are making decisions under conditions of knowledge uncertainty. So far, however, the eucalyptus problem has been addressed in a stagnated and unbalanced policy setting, dominated by the bureaucratic problem-framing and placation and manipulation of the local people with ambiguous professional explanations. The use of knowledge uncertainty to justify inaction is typical for a governance regime that operates within a closed professional knowledge system, does not accept a plurality of perceptions, and is not engaged in higher-level learning (Pahl-Wostl 2009).

The challenge for moving towards 'triple loop learning' and societal transformation is that the current asymmetric dynamic between local people and state bureaucrats consists of self-reinforcing mechanisms that continue to reproduce local people's subaltern position in resource management. Trust is hard to build. First, the bureaucrats' distrust of local knowledge as a source of legitimate evidence combined with dominant explanations based on professional knowledge, enhances the superiority of western natural science, a powerful myth which has been criticized and is often unjustified (Agrawal 1995; Watson 2013; Watson and Huntington 2008). This is especially harmful at the context where local peoples' confidence in their own cultural traditions and knowledge is already weakened due to long-term cultural oppression that has led to a general feeling of having 'lost control over both "tradition" and "modernity"' (Smith 2008, 12). The strong juxtaposition of exotic and indigenous trees has become the symbol of this crisis for many Taitas.

Bureaucratic attitudes towards local knowledge divert attention away from the unclear policies and internal incoherence existing in the formal environmental governance system, as well as from the inherently political questions of who benefits from forest resources. Ultimately, the exercise of bureaucratic power and economic interest is masked behind idealized guidelines that "are never specific enough to fit a local context" and "can operate as depoliticizing technologies" (Hoag 2011: 82). The problem with the guidelines is also that the professional knowledge they provide regarding the maximization of the production of wood biomass is produced to serve the economic interests of the state, which are not negotiated with local people whose lives and livelihoods are nevertheless affected by them. Overall, the interpretative schemes within the dominating professional/bureaucratic system produce environmental meanings that are in line with the economic values of that same system, and construct a structure of signification that reinforces the structure of domination (Jabri 1996). This contributes to the further assimilation of capitalist values among the community. At the same time, the professional knowledge system is not engaged in the production of knowledge on eucalyptus that may bring about better water conservation, and sit closer to local interests. Thus, knowledge asymmetry leads to conflict, driven by the power asymmetry between bureaucrats and local people (Noe et al. 2015). To enable true synergies between professional and local knowledge systems, the local logics, meanings and problem framing should be included and preferably taken as a starting point for building a dialogue. Only then could complementary insights from local, scientific and bureaucratic knowledge be used to create "an enriched picture" to find solutions to the problem (Tengö et al. 2014).

The current formal resource management system, however, is not able to facilitate collaboration as it refuses to take responsibility for the historical or future marginalization of local people in resource management and ownership. Rather than treating the public as commensurate actors, the officers considered people to be ignorant or in need of mobilization and education about the standard ways to organize themselves into user groups and to plan resource management. Besides creating new dependencies and the responsibilization of local people (Sletto and Nygren 2015), the neoliberal participatory mechanisms that operate through resource user associations do not recognize the historical and political context that has constructed local people's relationship with their environment and its management. This is a common problem in many post-colonial states in which decentralization processes work to open room for molding traditional community institutions in the image of the state's own modes of governance and policy objectives, and this increases its control over resources rather than empower local institutions (Mosse 2006; Rao 2005).

A lack of acknowledgement continues to reproduce the subaltern position of the Taita people, whose detachment from their traditional ecological knowledge and lack of confidence in their own heritage give them no validity for claiming rights on the basis of indigeneity (Taiaiake and Corntassel 2005). Ultimately, the challenges in integrating the knowledge base and values of bureaucrats and local people, combined with asymmetric power relations between them, continue to reproduce inequality in access to resources, a lack of 
recognition of the subjugated group in decision-making and thus, environmental injustice (Mehta et al. 2014; Schlosberg 2007).

\section{Conclusions}

This study has demonstrated the significant challenges that exist in collaboration and dialogue-building between local people and state actors in a context of power asymmetry. The Taita Hills have seen weakened confidence in local resource management and knowledge, through a form of bureaucratic oppression that is epistemological as well as embedded within the history of the region's governance. The eucalyptus policy problem in the Taita Hills is highly unstructured, due to disagreement between different actors, and anchored in historical trajectories. Better policy outcomes would require building trust between different actors, which should start from acknowledgement of the historical origins of injustice. That process is hindered by the current neoliberal forest management system, which is built on patronage and continued state control, and which, despite the establishment of participatory mechanisms and community resource user groups, has not been able to break free from reproducing colonial structures.

Moving towards building trust, an equal dialogue and social learning between local people and government actors would require that the government actors better understand their own position in this historically defined nexus of power, reconsider their underlying epistemological assumptions and settle questions of benefit-sharing as eucalyptus trees are logged. A collaborative approach requires functional bureaucracies that are transparent and reflexive regarding their own knowledge basis and interests. A more profound understanding of Taitas' local knowledge systems will help to revive the cultural significance of the indigenous forests and understanding of their importance. Environmental justice can only be achieved through recognizing a plurality of values (Walker 2009), which means moving beyond economic goals alone. Thus, the capitalist discourses adopted in knowledge assimilation need to be resisted to revive the pluralistic values of forests: not only as a source of timber, but also to preserve water resources, cultural and religious identities, social ties, nested in post-capitalist politics and community values (Gibson-Graham 2006).

\section{References}

Agrawal, A. 1995. Dismantling the divide between indigenous and scientific knowledge. Development and Change 26: 413-439.

Avelino, F. and J. Rotmans. 2009. Power in transition: an interdisciplinary framework to study power in relation to structural change. European Journal of Social Theory 12(4): 543-569.

Bentley, J. 1993. Old world encounters: cross-cultural contacts and exchanges in pre-modern times. New York, NY: Oxford University Press.

Berkes, F. 2012. Sacred ecology 3rd ed. New York, NY: Routledge.

Bhabha, H.K. 1995. The location of culture. London: Routledge.

Bixler, R.P. 2013. The political ecology of local environmental narratives: power, knowledge, and mountain caribou conservation. Journal of Political Ecology 20: 273-285.

Boelens, R., J. Hoogesteger and M. Baud. 2015. Water reform governmentality in Ecuador: neoliberalism, centralization, and the restraining of polycentric authority and community rule-making. Geoforum 64: 281-291.

Boelens, R., J. Hoogesteger, E. Swyngedouw, J. Vos and P. Wester. 2016. Hydrosocial territories: a political ecology perspective. Water International 41(1): 1-14.

Boiral, O. 2002. Tacit knowledge and environmental management. Long Range Planning 35(3): $291-317$.

Bravman, B. 1998. Making ethnic ways: communities and their transformations in Taita, Kenya, 1800-1950. Portsmouth, NH: Heinemann.

Cáceres, D., F. Silvetti and S. Díaz. 2016. The rocky path from policy-relevant science to policy implementation - a case study from the South American Chaco. Current Opinion in Environmental Sustainability 19: 57-66. 
Chomba, S.W., I. Nathan, P.A. Minang and F. Sinclair. 2015. Illusions of empowerment? Questioning policy and practice of community forestry in Kenya. Ecology and Society 20(3): 2.

Cortner, H. 2000. Making science relevant to environmental policy. Environmental Science and Policy 3: 2130.

Dear, M. and A. Burridge. 2005. Cultural integration and hybridization at the United States-Mexico borderlands. Cahiers de Géographie du Québec 49(138): 301-318.

Doughty, R. 2000. The eucalyptus: a natural and commercial history of the gum tree. Baltimore: The Johns Hopkins University Press.

Edelenbos, J., A. van Buuren and N. van Schie. 2011. Co-producing knowledge: joint knowledge production between experts, bureaucrats and stakeholders in Dutch water management projects. Environmental Science and Policy 14(6): 675-684.

Fernández-Llamazares, A., I. Díaz-Reviriego, M. Guèze, M. Cabeza, A. Pyhälä and V. Reyes-García. 2016. Local perceptions as a guide for the sustainable management of natural resources: empirical evidence from a small-scale society in Bolivian Amazonia. Ecology and Society 21(1): 2.

Fleischman, F. and D.D. Briske. 2016. Professional ecological knowledge: an unrecognized knowledge domain within natural resource management. Ecology and Society 21(1): 32.

Fleuret, P. 1985. The social organization of water control in the Taita Hills, Kenya. American Ethnologist 12 (1): 103-118.

Gerber, J.F. 2011. Conflicts over industrial tree plantations in the South: who, how and why? Global Environmental Change 21(1): 165-176.

Gerber, J.F. and S. Veuthey. 2010. Plantations, resistance and the greening of the agrarian question in coastal Ecuador. Journal of Agrarian Change 10(4): 455-481.

Gerber, J.F., S. Veuthey and J. Martínez-Alier. 2009. Linking political ecology with ecological economics in tree plantation conflicts in Cameroon and Ecuador. Ecological Economics 68(12): 2885-2889.

Gibson-Graham, J. K. 2006. A postcapitalist politics. Minneapolis: University of Minneasota Press.

Goldman, M. 2007. Tracking wildebeest, locating knowledge: Maasai and conservation biology understandings of wildebeest behavior in Northern Tanzania. Environment and Planning D: Society and Space 25: 307331.

Gómez-Baggethun, E., E. Corbera and V. Reyes-García. 2013. Traditional ecological knowledge and global environmental change: research findings and policy implications. Ecology and Society 18(4): 72.

Gómez-Baggethun, E. and V. Reyes-García. 2013. Reinterpreting change in traditional ecological knowledge. Human Ecology 41(4): 643-647.

Government of Kenya. 2002. The Water Act 2002. Nairobi, Kenya.

Government of Kenya. 2009. Agriculture (farm forestry) rules. Government Printer, Nairobi, Kenya.

Gramsci, A. 1999[1971]. Selections from the prison notebooks. Q. Hoare and G. Nowell Smith (eds.). London: ElecBook.

Harris, G. 1986. Casting out anger: religion among the Taita of Kenya. Prospect Heights, IL: Waveland Press.

Heynen, N., J. McCarthy, S. Prudham and P. Robbins (eds.) 2007. Neoliberal environments: false promises and unnatural consequences. New York, NY: Routledge.

Himberg, N. 2011. Traditionally protected forests' role within transforming natural resource management regimes in Taita Hills, Kenya. Ph.D. dissertation. Department of Geosciences and Geography A 14. Helsinki: University of Helsinki.

Hoag, C. 2011. Assembling partial perspectives: thoughts on the anthropology of bureaucracy. Political and Legal Anthropology Review 34(1): 81-94.

Hobley, C. W. 1895. Upon a visit to Tsavo and the Taita Highlands. The Geographical Journal 5(6): 545-561.

Hohenthal, J., P. Minoia and P. Pellikka. 2017. Mapping meaning: critical cartographies for participatory water management in Taita Hills, Kenya. The Professional Geographer 69(3): 383-395. 
Hohenthal, J., E. Owidi, P. Minoia and P. Pellikka. 2015. Local assessment of changes in water-related ecosystem services and their management: DPASER conceptual model and its application in Taita Hills, Kenya. International Journal of Biodiversity Science, Ecosystem Services and Management 11(3): 225238.

Hohenthal, J., M. Räsänen, E. Owidi, B. Andersson, P. Minoia and P. Pellikka. 2015. Community and institutional perspectives on water management and environmental changes in the Taita Hills, Kenya. Department of Geosciences and Geography C11. Helsinki: University of Helsinki.

Hunt, J. and S. Shackley. 1999. Reconceiving science and policy: academic, fiducial and bureaucratic knowledge. Minerva 37: 141-164.

Hurlbert, M. and J. Gupta. 2015. The split ladder of participation: a diagnostic, strategic, and evaluation tool to assess when participation is necessary. Environmental Science and Policy 50: 100-113.

Jabri, V. 1996. Discourses on violence: conflict analysis reconsidered. Manchester: Manchester University Press.

Jandreau, C. and F. Berkes. 2016. Continuity and change within the social-ecological and political landscape of the Masai Mara, Kenya. Pastoralism: Research, Policy and Practice 6(1): 1-15.

Keeley, J. and I. Scoones. 2003. Understanding environmental policy processes: cases from Africa. London: Earthscan.

Kenya Forest Service. 2009. A guide to on-farm eucalyptus growing in Kenya. Nairobi, Kenya: Kenya Forest Service.

Lovett, J. and S. Wasser. 1993. Biogeography and ecology of rainforests of Eastern Africa. Cambridge, UK: Cambridge University Press.

Maathai, W. 2004. The Green Belt Movement: sharing the approach and the experience. New York, NY: Lantern Books.

Mehta, L., J. Allouche, A. Nicol and A. Walnycki. 2014. Global environmental justice and the right to water: the case of peri-urban Cochabamba and Delhi. Geoforum 54: 158-166.

Merritt, E. 1975. A history of the Taita of Kenya to 1900. Ph.D. dissertation. Bloomington, IN: Indiana University.

Millennium Ecosystem Assessment Board. 2005. Living beyond our means. Natural assets and human wellbeing. Statement from the board. [accessed October 26 2017].

Minoia, P. 2012. Mega-irrigation and neoliberalism in postcolonial states: evolution and crisis in the Gharb Plain, Morocco. Geografiska Annaler, Series B: Human Geography 94(3): 269-286.

Mosse, D. 2006. Collective action, common property, and social capital in South India: an anthropological commentary. Economic Development and Cultural Change 54(3): 695-724.

Mumma, A. 2007. Kenya's new water law: an analysis of the implications of Kenya's Water Act, 2002, for the rural poor. In B. van Koppen, M. Giordano and J. Butterworth (eds.) Community-based water law and water resource management reform in developing countries. Wallingford: CAB International. Pp. 158172.

Nadasdy, P. 1999. The politics of TEK: power and the "integration" of knowledge. Arctic Anthropology 36(12): 1-18.

Newmark, W.D. 1998. Forest area, fragmentation, and loss in the Eastern Arc Mountains: implications for the conservation of biological diversity. Journal of East African Natural History 87(1): 29-36.

Nightingale, A.J. 2015. Challenging the romance with resilience: communities, scale and climate change. In W. Harcourt and I.L. Nelson (eds.) Practicing feminist political ecologies: moving beyond the "green economy". London: Zed. Pp. 182-208.

Noe, E., H.F. Alrøe, M.H. Thorsøe, J.E. Olesen, P. Sørensen, B. Melander and E. Fog. 2015. Knowledge asymmetries between research and practice: a social systems approach to implementation barriers in organic arable farming. Sociologia Ruralis 55(4): 460-482. 
Nygren, A. 1999. Local knowledge in the environment-development discourse: from dichotomies to situated knowledges. Critique of Anthropology 19(3): 267-288.

Oballa, P.O., P.K.A. Konuche, M.N. Muchiri and B.N. Kigomo. 2010. Facts on growing and use of eucalyptus in Kenya. Nairobi, Kenya: Kenya Forestry Research Institute.

Ogendi, G. and I. Ong'oa. 2009. Water policy, accessibility and water ethics in Kenya. Santa Clara Journal of International Law 7(1): 177-196.

Pahl-Wostl, C. 2009. A conceptual framework for analysing adaptive capacity and multi-level learning processes in resource governance regimes. Global Environmental Change 19(3): 354-365.

Paulson, S., L.L. Gezon and M.J. Watts. 2003. Locating the political in political ecology: an introduction. Human Organization 62(3): 205-217.

Pearce, T., J. Ford, A. Cunsolo Willox and B. Smit. 2015. Inuit traditional ecological knowledge (TEK), subsistence hunting and adaptation to climate change in the Canadian Arctic. Arctic 68(2): 233-245.

Pellikka, P.K.E., M. Lötjönen, M. Siljander and L. Lens. 2009. Airborne remote sensing of spatiotemporal change (1955-2004) in indigenous and exotic forest cover in the Taita Hills, Kenya. International Journal of Applied Earth Observation and Geoinformation 11(4): 221-232.

Pottier, J. 2003. Negotiating local knowledge: an introduction. In J. Pottier, A. Bicker and P. Sillitoe (eds.) Negotiating local knowledge: power and identity in development. London: Pluto Press. Pp. 1-29.

Pyhälä, A., Á. Fernández-Llamazares, H. Lehvävirta, A. Byg, I. Ruiz-Mallén, M. Salpeteur and T. Thornton. 2016. Global environmental change: local perceptions, understandings, and explanations. Ecology and Society 21(3): 1-27.

Rao, V. 2005. Symbolic public goods and the coordination of collective action: a comparison of local development in India and Indonesia. Washington, DC: Development Economics Research Group, World Bank.

Raymond, C.M., I. Fazey, M.S. Reed, L.C. Stringer, G.M. Robinson and A.C. Evely. 2010. Integrating local and scientific knowledge for environmental management. Journal of Environmental Management 91(8): 1766-1777.

Republic of Kenya. 2005. The Forest Act 2005. Kenya Gazette Supplement No. 88 (Acts No. 7). Nairobi.

Republic of Kenya. 2010. The constitution of Kenya. National Council for Law Reporting with the Authority of the Attorney General. Nairobi.

Republic of Kenya. 2014. Forest policy. Ministry of Environment, Water and Natural Resources. Nairobi.

Robbins, P. 2012. Political ecology, a critical introduction. Oxford: Wiley-Blackwell.

Schlosberg, D. 2007. Defining environmental justice: theories, movements, and nature. New York, NY: Oxford University Press.

Seghezzo, L., J.N. Volante, J.M. Paruelo, D.J. Somma, E.C. Buliubasich, H.E. Rodriguez, S. Gagnon and M. Hufty. 2011. Native forests and agriculture in Salta (Argentina): conflicting visions of development. The Journal of Environment and Development 20(3): 251-277.

Sillitoe, P. (ed.). 2007. Local science vs global science: approaches to indigenous knowledge and international development. New York, NY: Berghahn.

Sletto, B. and A. Nygren. 2015. Unsettling neoliberal rationalities: engaged ethnography and the meanings of responsibility in the Dominican Republic and Mexico. International Journal of Urban and Regional Research 39(5): 965-983.

Smith, J. 2008. Bewitching development. witchcraft and the reinvention of development in neoliberal Kenya. Chicago, IL: The University of Chicago Press.

Spivak, G. 1988. Can the subaltern speak? In C. Nelson and L. Grossberg (eds.). Marxism and the interpretation of culture. Urbana/Chicago: University of Illinois Press. Pp. 66-111.

Taiaiake, A. and J. Corntassel. 2005. Being indigenous: resurgence against contemporary colonialism. Government and Opposition 40(4): 597-614. 
Tengö, M., E.S. Brondizio, T. Elmqvist, P. Malmer and M. Spierenburg. 2014. Connecting diverse knowledge systems for enhanced ecosystem governance: the multiple evidence base approach. Ambio 43(5): 579591.

Thygesen, S.H., T. Løber, E.M. Skensved and C.P. Hansen. 2016. Implementation of participatory forest management in Kenya: a case study of Karima Forest. International Forestry Review 18(3): 357-368.

Turnbull, D. 2000. Masons, tricksters and cartographers: comparative studies in the sociology of scientific and indigenous knowledge. Amsterdam: Harwood.

Turner, M.D. 2014. Political ecology I: an alliance with resilience? Progress in Human Geography 38(4): 616623.

Turner, N., M. Boelscher Ignace and R. Ignace. 2000. Traditional ecological knowledge and wisdom of aboriginal peoples in British Columbia. Ecological Applications 10(5): 1275-1287.

United Nations. 2008. United Nations declaration on the rights of indigenous peoples. United Nations.

United Nations. 2015. Draft outcome document of the United Nations summit for the adoption of the post-2015 development agenda. United Nations General Assembly 12 August 2015.

Waaijenberg H. 2000. Chapter 12, Agriculture. In J. Hoorweg, D. Foeken, R.A. Obudho (eds.) Kenya Coast handbook. Culture, resources and development in the East African littoral. Leiden: African Studies Centre. Pp. 175-196.

Walker, G. 2009. Beyond distribution and proximity: exploring the multiple spatialities of environmental justice. Antipode 41(4): 614-636.

Watson, A. 2013. Misunderstanding the "nature" of co-management: a geography of regulatory science and indigenous knowledges (IK). Environmental Management 52: 1085-1102.

Watson, A. and O. Huntington. 2008. They're here - I can feel them: the epistemic spaces of Indigenous and Western Knowledges. Social and Cultural Geography 9(3): 257-281.

Water Resource Management Authority. 2012. Strategic Plan 2012-2017. Nairobi, Kenya: Water Resource Management Authority.

Yeh, E.T. 2016. "How can experience of local residents be 'knowledge'?" Challenges in interdisciplinary climate change research. Area 48(1): 34-40. 